\title{
Fund Collection through Litigation by The State Treasury in the RoMan EMPIRE (WITH SPECIAl Reference to THE First Three Centuries A.D.)
}

One of the sources of revenue for the State Treasury was funds gained through litigation pertaining in particular to confiscation arising from convictions for the most grave crimes, especially those of a political nature. Publicatio bonorum, the Latin name for this sanction, implies that the confiscated goods were due to aerarium, that is the State Treasury: the verb publicare means to make "available to the public", "make something public property", "to make public". Over time, with the personal treasury of the Emperor (fiscus) having been established as part of the State Treasury, a portion of the confiscated property was designated to supply - apart from aerarium - both the above-mentioned personal treasury and the personal property of the Emperor (patrimonium).

What calls for an explanation is the denotation (in fact, many denotations) of the term fiscus. Taken literally, fiscus meant a basket; since baskets were commonly used as money depositories, the term started to be associated with private funds ${ }^{1}$. During the Republic period, and then in the period of the Principate, fiscus started to stand for public funds managed by a province administrator; for example, when Tacitus mentioned that, following the earthquake in Asia, Augustus ordered a 5-year public exemption for the inhabitants of the town of Sardes from all State Treasury fees and fees due to the Emperor's Treasury (quantum aerario aut fisco pendebant ${ }^{2}$ ), by the latter he meant provincial funds ${ }^{3}$. At the outset of the

\footnotetext{
1 E.g. fiscos parare, to prepare money (for a journey - Lucius AnNaEus SeneCa, Epistulae, CXIX, 5, trans. R.M. Gummere, Cambridge Mass. 1953); to pay exsuo fisco, i.e. out of one's own pocket (VAlerius Maximus, Factorum et dictorum memorabilium libri novem, VI, 2, 11, rec. K.F. KeMPF, Lipsiae 1888).

2 Tacitus, Libri ab excessu divi Augusti, II, 47, ed. P.K. Huibregtse, vol. I, Groningen 1958 (cetera: TACITUs, Annales).

3 See also e.g. Marcus Tullius Cicero, In Verrem, II, 3, 197, [in:] Scripta quae manserunt omnia, rec. R. Klotz, vol. I, pars 2, Lipsiae 1869: Ego habebo et in cistam transferam de fisco; Suetonius, De vita caesarum / The Lives of the Caesars, II, 101, trans. J.C. Rolfe, London-New York 1914 (cetera: SuetoNIUs), vol. I: tertio [sc. volumine] breviarium totius imperii, quantum militum sub signis ubique esset, quantum
} 
Principate, the discussed term, in both its above-mentioned meanings, began to make reference to the Emperor: first of all, it could denote his private property, also called patrimonium. Numerous fragments of Res Gestae Divi Augusti, in which the Emperor calculates the expenditures from his own property incurred for public use, exemplify this. The document itself was described as a record of what Augustus achieved and of the expenditures he incurred for the State (quas in rem publicam populumque Romanum fecit). Apart from diverse expenditures on military and victualling for the Roman people, one needs to mention expenditures on temples and sanctuaries raised by Augustus, costs incurred for the renovation of public buildings, for putting together the games and, last but not least, funds deployed to construct Aqua Virgo and refurbish other aqueducts ${ }^{4}$. Many of those expenses were ideologically construed as emanating from the liberalitas of the princeps. Elio Lo Cascio points out that distributions of coin (congiaria) and of corn (frumentationes) to the metropolitan plebs, handouts to the troops (donativa), and more generally personal gifts of the emperor were the clearest expression of this ideology. But the involvement of the imperial financial administration in the provision of infrastructure such as roads, aqueducts, bridges, and harbors fell in the same category of indulgentia ${ }^{5}$. Described in Res Gestae, such generosity of the princeps in deploying funds from the State Treasury was on the one hand attributable to moral responsibility for the well-being of the Empire, but, on the other, strengthened his influence on the State's finances and administration in a major way ${ }^{6}$. The term under discussion understood as the private property of the Emperor can be found in a well-known extract from De beneficiis by Seneca:

Caesar omnia habet, fiscus eius privata tantum ac sua et universa in imperio eius sunt, in patrimonio propria. Quid eius sit, quid non sit, sine diminutione imperii quaeritur; nam id quoque, quod tamquam alienum abiudicatur, aliter illius est. ${ }^{7}$

pecuniae in aerario et fiscis et vectigaliorum residuis (cf. TAcitus, Annales, I, 11); SuETonius, IV, 16, 1: Rationes imperii ab Augusto proponi solitas sed a Tiberio intermissas publicavit (cf. CAssius Dio Cocceianus, Historia Romana, LIX, 9, trans. E. CARY, H.B. Foster, vol. VII, Cambridge 1959 [cetera: Dio CAssius]). 4 Cf. Dio Cassius, LIII, 21; LIV, 11, 7; Frontinus, The Strategems and the Aqueducts of Rome, II, 128, trans. C.E. BenEtT, Cambridge 1961.

5 E. Lo Cascio, The Early Roman Empire: the State and the Economy, [in:] The Cambridge Economic History of the Greco-Roman World, ed. W. Scheidel, J. Morris, R. SAller, Cambridge 2007, p. 632. According to the author, imperial expenditure complemented expenditure by the municipalities and by private benefactors and was chiefly directed at big projects which could not otherwise have been funded: the construction of the two big harbours at the mouth of Tiber or the draining of the Fucine Lake are among the most prominent examples. On the influence of emperors' policy on economic growth see more: R.B. Hitchner, The Advantages of Wealth and Luxury. The Case for Economic Growth in the Roman Empire, [in:] The Ancient Economy. Evidence and Models, ed. J.G. Manning, I. MorRIs, Stanford 2005, p. 208sq.

6 C.H.V. Sutherland, Aerarium and Fiscus during the Early Empire, AJP 66.2, 1945, p. 155.

7 Lucius Annaeus Seneca, De beneficiis, VII, 6, 3, [in:] idem, Moral Essays, trans. J.W. Bassore, vol. III, Cambridge 1958 (cetera: SENECA, De beneficiis). 
This is why, secondly, fiscus is associated with funds under the Emperor's control, representing both his private property and the property of the public. Last but not least, in broadest terms, it was used to describe the entire financial administration under the Emperor's control ${ }^{8}$. The first literary publication in which the term appeared with this meaning was in a piece by Seneca. There, while contemplating the degree to which a promise is binding, the author states that he is not willing to stand surety for an unspecified amount, and - which he apparently finds equally vague - to assume liabilities towards the treasury: Sponsum descendam, quia promisi; sed non, si spondere me in incertum iubebis, si isco obligabis ${ }^{9}$. In this context, fiscus means the financial management exercised by the Emperor ${ }^{10}$. With the passage of time, public property and revenue almost entirely fell under the Emperor's scrutiny; from the $3^{\text {rd }}$ century onwards, the term fiscus used in classical Roman law and literature became synonymous with aerarium ${ }^{11}$. Sometimes, lawyers tend to accentuate the denotational difference between ratio privata or res privata, i.e. the Emperor's private property, and fiscus, understood as 'state funds' 12 .

Judging by the way some of the trials were handled, one could get the impression that they were inspired on purpose, in order to confiscate and, consequently, to supply not only public property, but the private treasury of the Emperors as well. As early as in 26 B.C., the Senate voted that the property confiscated from Cornelius Gallus - appointed the first prefect of Egypt in 30 B.C., who fell into the disgrace of the princeps, as he ordered that monuments of him be put up in the province that he governed, and inscriptions on pyramids be made to praise his acts (also, Gallus criticised Augustus) - be adjudged in respect of Augustus ${ }^{13}$. In 6 A.D., as Archelaus, an ethnarch from Judea, was sentenced to exile, his property was confiscated for the benefit of the Emperor's treasury, which may also mean the private Emperor's fund ${ }^{14}$. Tiberius, the successor of Augustus, was, to quote Tacitus, at least to a certain point in time quite reluctant to yield to money (satis firmus adversus pecuniam ${ }^{15}$ ). During the litigation against Gnaeus Calpurnius Piso, accused of poisoning Germanicus, the

\footnotetext{
8 A.H.M. Jones, The Aerarium and the Fiscus, [in:] IDEM, Studies in Roman Government and Law, Oxford 1960, p. 107; P.A. BRunt, The "Fiscus" and its Development, JRS 56, 1966, p. 75.

9 SenECA, De beneficiis, IV, 39, 3.

10 A.H.M. Jones, op. cit., p. 107-108; see also: Plinius, Naturalis Historia, VI, 84, trans. H. Rackham, Cambridge 1942; XII, 113, trans. H. Rackham, Cambridge 1940 (cetera: Plinius).

${ }^{11}$ See e.g. Digesta XLIX, 14, 13 (Paulus), rec. T. Mommsen, [in:] Corpus Iuris Civilis, vol. I, ${ }^{10}$ Berolini 1906 (cetera: Dig.); XLIX, 14, 15 (Iunius Marcianus).

12 See e.g. Dig., XLIX, 14, 6, 1 (Ulpianus): Quodcumque privilegii fisco competit, hoc idem et Caesaris ratio, et Augustae habere solet; XLIX, 14, 3, 10 (Callistratus): Si in locis fiscalibus, vel publicis religiosisve, aut in monumentis thesauri reperti fuerint, Divi Fratres constituerunt, ut dimidia pars ex his fisco vindicaretur; item si in Caesaris possessione repertus fuerit, dimidiam aeque partem fisco vindicari. In the last extract the author most probably has in mind ratio privata.

13 Cassius Dio, LIII, 23.

14 Iosephus Flavius, Bellum Iudaicum, II, 7, 3.

15 Tacitus, Annales, III, 18.
} 
nephew and adopted son of Tiberius, in Antioch, some of the senators were in favour of confiscating, i.a., part of his property. The Emperor, however, decided to assign the property to the convict's son, Marcus, the rationale being, according to the author of Annales, the very lack of greediness of the convict ${ }^{16}$. The last statement, however, is worth a closer look, as it seems to imply that, since Tiberius agreed that Piso's property be claimed by his son, because the former did not care about money, he must have had a personal interest in the confiscation - with the property being forfeited exclusively for the benefit of State Treasury, the Emperor's standpoint in this case would be of no relevance ${ }^{17}$. The reluctance of Tiberius towards confiscation was stressed a couple of times by Cassius Dio; the historian claims that during his reign there were no instances of convictions substantiated by the motivation of gaining profits; also, no cases of publicatio bonorum were recorded ${ }^{18}$. The statements put forward by Dio are, however, not entirely true, since at some point it began to transpire that also Tiberius took interest in somebody else's property (erga pecunia aliena diligentia). In 22 A.D., the case of Gaius Sylius, who in 14-21 A.D. acted as an imperial legate of Upper Germania, was brought to court. His talents as a leader became evident, i.a. during the 21 A.D. Sakrovir revolt in Gaul, for which he was honoured with ornamenta triumphalia; it is also worth noting that, with the widespread revolts that took place in the legions at that time, he managed to persuade the soldiers to stay calm after the death of Augustus ${ }^{19}$. With his person gaining in importance, and the friendship that his wife Sosia had with Agrippina - suspected of leading a movement striving to split the country ${ }^{20}$ - he was eventually accused by Lucius Visellius Varro, a consul, of being indolent in suppressing the Sakrovir revolt, indulging in acts of extortion within the area of the province (where, allegedly, his wife was the accomplice), and lese-majesty. The practice of combining repetundae and crimen maiestatis accusations dates back to 15 A.D., when the trial of a former imperial legate of Bithynia, Granius Marcellus, took place, whereby particular implications for its development had charges levelled against the former proconsul of the Asia province, Gaius Junius Silanus, as the senatusconsultum adopted in this case became the legal basis for passing sentences in many other incriminations of such type ${ }^{21}$. Tacitus's comment on similar litigation instigated against Caesius Cordus, the proconsul of Crete, suggests that the lese-majesty charge became a "business as usual" accusation, being regularly used as an additional accusation in litigation, most probably to ensure that the chance of convicting the defendant was higher: addito maiestatis

\footnotetext{
16 Tacitus, Annales, III, 19.

17 P.A. BRunt, op. cit., p. 82.

18 Dio Cassius, Historia Romana, LVII, 10, 5 and 18, 8; LVIII, 21, 6. See also: M. Dyjakowska, Crimen laesae maiestatis. Studium nad wpływami prawa rzymskiego w dawnej Polsce, Lublin 2010, p. 58-59.

19 TACitus, Annales, I, 72; IV, 18.

20 TaCitus, Annales, IV, 17.

${ }^{21}$ See more: R. SAJKowski, Oskarżenia o obrazę majestatu w procesach de repetundis. Obwinienie Gajusza Juniusza Sylanusa z roku 22 n.e., CPH 51, 1999, p. 347sqq.
} 
crimine, quod tum omnium accusationum complementum erat ${ }^{22}$. All activities which could potentially spark public unrest in the country, and the acts of extortions in the provinces, including in particular those accompanied by violence, were seen as lesemajesty to the Emperor ${ }^{23}$. Yet in the course of the litigation proceedings, Sylius committed suicide, which, however, did not result in their discontinuation and did not stop the verdict from being passed. Asinius Gallus put forward a motion to banish Sosia and to confiscate half of her property (the second part thereof was to be assigned to the children); however, it seems that the senate accepted the proposal by Manius Lepidus to furnish the children of the convicted with $3 / 4$ of the property and leave the rest for the prosecutors. In turn, confiscation was adjudged with regard to the property held by Sylius, with the portion intended as a donation to Augustus, which was supposed to go back to the Emperor's treasury, being deducted: liberalitas Augusti avulsa, computatis singillatim quae fisco petebantur ${ }^{24}$. As indicated by the comment made by Tacitus, the claims put forward by the treasury may have resulted from an inheritance established in the past by Augustus - following the confiscation, Tiberius demanded that the property be returned. Peter A. Brunt makes the point that the legal acts lacked the provisions providing for the right of a private donor to retrieve a donation received from a legally-convicted person (in this case the conviction due to repetundae and maiestas); even if the Emperor - or rather the senate - had decided to establish the right to demand the donation to be given back by the person, who could be reproached about being ungrateful, it would not have supported the decision to pass the entire convict's property to the Emperor, which had already taken place in other cases during the reign of Tiberius ${ }^{25}$. And so, with Aelius Sejanus's death sentence passed in 31 A.D., the senate demanded that his property be adjudged in respect of the Emperor's private treasury rather than for the benefit of the public treasury: bona Seiani ablata aerario ut in fiscum cogerentur ${ }^{26}$. However, insofar as Sejanus's trial resulted from plotting against Tiberius and his excessive political aspirations, and the property confiscation - along with the collective liability of the members of his family ${ }^{27}$ - was seen as an additional penalty ${ }^{28}$, Tacitus makes a clear case that the conviction of Sextus Marius was driven by the Emperor's profit motivation, the litigation itself being a sham: ac ne dubium haberetur magnitudinem pecuniae malo vertisse, aurariasque eius, quamquam publicarentur, sibimet Tiberius seposuit ${ }^{29}$.

\footnotetext{
22 TaCitus, Annales, III, 38.

${ }^{23}$ R.A. Bauman, Impietas in Principem. a study of treason against the Roman Emperor with special reference to the first century A.D., Munich 1974, p. 92 sqq; R. SAJкоwsкi, Oskarżenia..., p. 347-357; IDEM, Wybrane problemy oskarżenia Gajusza Syliusza i jego małżonki Sozji, SPu 7, 2007, p. 107-108.

24 TaCitus, Annales, IV, 26.

25 P.A. BRunT, op. cit., p. 81-82.

26 TAcitus, Annales, VI, 2.

27 Tacitus, Annales, V, 9.

${ }_{28}$ U. Brasiello, La repressione penale in diritto Romano, Napoli 1937, p. 112-113.

29 Tacitus, Annales, VI, 20.
} 
The relevant extract does not make it clear that the mines were the property of the Emperor, since Tacitus employed the term seponere, which he had previously used to describe the administration exercised by Augustus in Egypt, where the majority of land, being royal property, became the property of the Roman Empire ${ }^{30}$. Therefore, it may be assumed that it was not the confiscated mines, which remained public property, that Tiberius reserved his right to, but the right to manage them ${ }^{31}$. It is worth noting that, as pointed out by Cassius Dio, Marius was a friend of Tiberius, thanks to whom he became rich; hence, the assumption of the right to manage the mines by the Emperor may have been a way of retrieving the donations made earlier in respect of the convict ${ }^{32}$. This event may imply that the practice based on which fiscus, understood as the personal property of the Emperor, set up claims to those goods that should remain public property, or at least to manage those goods, takes its origin in the judicature of the senate: senatusconsulta led to precedents which, eventually, established themselves as rules ${ }^{33}$. Even though, as may be inferred from the words of Plinius, as early as during the times of Domitian crimen maiestatis litigation contributed to supplying both the State Treasury and the Emperor's treasury (locupletabant et fiscum et aerarium non tam Voconiae et Iuliae leges quam maiestatis singulare et unicum crimen eorum qui crimine vacarent ${ }^{34}$ ), over time, fiscus, also understood as public property managed by the Emperor, became the sole beneficiary of the confiscated property; the publicare term became synonymous with fisco vindicare ${ }^{35}$.

Caligula, the successor of Tiberius, is described by historians as a ruler who would seize the confiscated property for the benefit of his personal belongings. This was the case, e.g., with Avilius Flaccus, the protagonist of the piece by Philo of Alexandria, entitled In Flaccum, who in 32 A.D. was appointed by Tiberius the impe-

\footnotetext{
30 TACITUs, Annales, II, 59: nam Augustus inter alia dominationis arcana, vetitis nisi permissu ingredi senatoribus aut equitibus Romanis inlustribus, seposuit Aegyptum ne fame urgeret Italiam quisquis eam provinciam claustraque terrae ac maris quamvis levi praesidio adversum ingentis exercitus insedisset.

${ }_{31}$ P.A. BRUnT, op. cit., p. 82; a different hypothesis is put forward by T. WAŁEK-CZERNECKI, who claims that what Tacitus meant was incorporating the confiscated goods into patrimonium principia: according to the author, the legal forms were preserved, i.e. the confiscated goods were purchased through public sale, where, oviously, nobody could compete with the Emperor - Historia gospodarcza świata starożytnego, vol. II, Grecja-Rzym, Warsaw 1948, p. 304. At the beginning of the Empire, particulary during the reign of Tiberius, many mines were seized by the fiscus, at least in some regions such as southern Spain. In recently incorporated areas - above all northern Spain, which was to become the richest source of gold for the imperial mint - the local mines had become imperial property upon conquest and were directly exploited by the imperial administration: colossal investments, possible only for the emperor, were required to extract ore with the help of complex waterpower devices - E. Lo CAscio, op. cit., p. 643.

${ }^{32}$ F. Millar, The Fiscus in the First Two Centuries, JRS 53, 1963, p. 37. See also: Dio Cassius, Historia Romana, LVIII, 22.

33 P.A. BRUnT, op. cit., p. 82.

${ }_{34}$ Plinius, Panegyricus, 42, 1, [in:] C. Plinii Secundi Epistularum libri novem; Epistolarum ad Traianum liber; Panegyricus, ed. M. Schuster, R. Hanslik, Lipsiae 1958.

35 See e.g. Dig., XLVIII, 20, 7, 7 (Paulus); XLVIII, 20, 8 (Marcianus); XXI, 3, 8 (Marcianus).
} 
rial legate of Alexandria, Egypt and Libya. Following the death of Tiberius and the takeover of power by Caligula in 37 A.D., he was afraid that the new Emperor would take revenge on him for the death of his mother, Agrippina the Elder, in whose trial he had participated in 29 A.D. Having lost his protectors: co-Emperor Gemellus, murdered on the orders of Caligula, and then Macro, the commander of the Roman Preaetorian Guard who was appointed the new Governor, Flaccus struck up an alliance with Isidore, Lampo and Dionysius - Alexandrian rebels employed by Caligula as the delators (public accuser). The allies coerced him into issuing an anti-Jewish edict which gave rise to the persecutions of Jews in 38 A.D. Flaccus did not manage to escape the purge: halfway into the October of 38 A.D. he was arrested and transported to Rome to be tried in a case prosecuted by those who until recently had been his confederates - Isidore and Lampo. He was probably charged with lese-majesty and improper governance over the province. The trial resulted in Flaccus being exiled to an island and his property being confiscated: Philo of Alexandria did not miss the fact that, although many of the confiscated belongings were put up for public auction, it was only the property of Flaccus that got requisitioned by the Emperor ${ }^{36}$. The same author points out that Caligula appropriated all the properties of convicts; he would even convict many affluent citizens for the sole purpose of robbing them of their possessions $s^{37}$, an opinion confirmed by Cassius Dio $^{38}$.

In Scriptores Historiae Augustae, the biographer of the Emperor Hadrian credits this ruler with making the significant decision to provide that bona damnatorum be confiscated for the benefit of aerarium publicum rather than to be due to the private treasury of the Emperor - fiscus privatus: Damnatorum bona in fiscum privatum redigi vetuit omni summa in aerario publico recepta ${ }^{39}$. This way, Hadrian eliminated all suspicions that the litigation instigated for legal actions was launched for the purpose of gaining private benefits, the more so since the defendants in these trials were his political rivals ${ }^{40}$. Those who came after Hadrian did not always follow his methods: among those reproached for taking advantage of the confiscated goods to accumulate private property was Septimius Severus, whose reign saw the public treasury being formally separated from the Emperor's private property:

Interfectis innumeris Albini partium viris, inter quos multi principes civitatis, multae feminae inlustres fuerunt, omnium bona publicata sunt aerariumque auxerunt; cum et Hispanorum et Gallorum proceres multi occisi sunt. (...) Filiis etiam suis ex hac proscriptione tantum reliquit quantum nullus imperatorum, cum magnam partem auri per Gallias, per Hispanias, per Italiam imperatoriam fecisset. Tuncque primum privatarum rerum procuratio constituta est. ${ }^{41}$

\footnotetext{
${ }^{36}$ Philo Alexandrinus, In Flaccum, 150.

37 Philo Alexandrinus, Legatio ad Gaium, 341.

38 Dio Cassius, Historia Romana, LIX, 10, 6 - 11, 5; 21, 4.

39 Scriptores Historiae Augustae: Vita Hadriani, 7, tr. D. MAGIE, London-New York 1960 (cetera: SHA).

40 K. Amielańczyк, Polityka fiskalna cesarza Hadriana w sprawach karnych, [in:] Podstawy materialne państwa. Zagadnienia prawno-historyczne, ed. D. Bogacz, M. Tkaczuk, Szczecin 2006, p. 591-592.

${ }^{41}$ SHA: Vita Severi, 12.
} 
According to Suetonius, Domitian had not come over as being greedy before he took over rule - on the contrary, he was known to have made efforts to quell signs of greediness among the officials and the denouncers (delators) ${ }^{42}$; over time, however, with the State Treasury becoming half empty, he would not hesitate to resort to dishonourable means of getting funds, i.a., through - as may be inferred from the above-mentioned extract of Panegyric - fabricated litigation cases, mostly those involving lese-majesty:

Bona vivorum ac mortuorum usquequaque quolibet et accusatore et crimine corripiebantur. Satis erat obici qualecumque factum dictumve adversus maiestatem principia. ${ }^{43}$

During the legal proceedings against Gaius Junius Sylanus a discussion took place in the Senate in which the issue was raised as to what portion of the property should be due to the children of the convict. It is hard to establish what the usually-applicable amount was at that time. Tacitus, for example, reports that in the case of Publius Sulius, charged with - as was also the case with many a predecessor of his - i.a. extortions and misappropriation of public money, the acts he allegedly committed while being the governor of Asia, as well as numerous crimes committed in Rome, part of his belongings was confiscated, with the remaining property being left at the disposal of his son and granddaughter ${ }^{44}$. The description of the trial against Gnaeus Calpurnius Piso ${ }^{45}$ also does not provide information on the proportion of the property that was proposed by the Senators for confiscation, and the part of the belongings to be transferred to his son. In Scriptores Historiae Augustae, in turn, the author of Hadrian's biography credits the Emperor with ensuring that all the convict's children be granted one-twelfth of his property: Liberis proscriptorum duodecimas bonorum concessit" 46 . However, even sources of law do not provide clear information as to how big the proportion in question was. It may be safely assumed, though, that what was taken into consideration was the hypothetical proportion that would be due to children based on intestacy, since in Digesta Callistratus refers ${ }^{47}$ to the rescript issued by the "divine brothers", i.e. Marcus Aurelius and Lucius Verus, in the light of which, where half the property is confiscated, children are not entitled to the part of the property exempt from garnishment:

Liberis eius, cui pars dimidia duntaxat bonorum ablata est, partes non dantur. Idque et Divi Fratres rescripserunt.

\footnotetext{
${ }^{42}$ Suetonius, VIII, 9.

43 Suetonius, VIII, 12.

44 Tacitus, Annales, XIII, 44.

45 Tacitus, Annales, III, 17.

46 SHA: Via Hadriani, 18, 3.

47 Dig., XLVIII, 20, 1, 3.
} 
What is more, the Codex Hermogenianus issued in the times of Septimius Severus ordered that the crimen maiestatis convict's property be in the first place transferred to his descendants, whereby the confiscation for the benefit of the Emperors' treasury could be effected only where the convict had no descendants:

Eorum, qui maiestatis crimine damnati sunt, libertorum bona liberis damnatorum conservari, Divus Severus decrevit, et tunc demum fisco vindicari, si nemo damnati liberorum existat ${ }^{48}$.

The privilegies for children (portiones concessae) are also mentioned in two passages of Callistratus' work De iure fisci. In the first one the author described the terms upon which the children of a condemned person could obtain a part of his property:

Damnatione bona publicantur, cum aut vita adimitur aut civitas, aut servilis condicio irrogatur. Etiam si qui ante concepti et post damnationem nati sunt portiones ex bonis patrum damnatorum accipiunt. Liberis autem ita demum portio tribuitur, si iustis nuptiis nati sint (...). ${ }^{49}$

The confiscation of the whole property (publicatio bonorum) was the consequence of the infliction of the following penalties: poena capitalis, a loss of nationality or loss of freedom. To acquire portiones concessae it was necessary for children both to be conceived before a crime was committed (although born after the conviction) and to be legitimate. The infliction of other penalties resulted in partial confiscation (ademptio bonorum).

The second passage relates to a dowry appointed for a daughter before her parent was sentenced, which is connected to the problem of confiscation of property. The sentence did not give the fisc [tax service] any rights to become the owner of a daughter's dowry, even if she later (i.e. after her parent's conviction) died at the time of her marriage, unless it had been proved that a parent had bestowed something upon his children out of fear of the punishment (metu condemnationis):

Si condemnatur pater, qui dotem pro filia dedit, fisco in eam dotem ius non est, etiamsi postea in matrimonio filia moriatur, nisi probabitur patrem metu condemnationis liberis prospexisse. ${ }^{50}$

It was not until the Emperors Arcadius and Honorius issued Lex Quisquis in 397 (bonis eius omnibus fisco nostro addictis ${ }^{51}$ ) that confiscation was established as an obligatory sanction for all forms of crimen maiestatis with the view of discrediting the convict's family in society, along with other repressions towards his children ${ }^{52}$.

\footnotetext{
${ }_{48}$ Dig., XLVIII, 4, 9.

${ }^{49}$ Dig., XLVIII, 20, 1.

${ }^{50}$ Dig., XLVIII, 20, 9.

${ }^{51}$ CJ, IX, 8, 5 pr., rec. et retr. P. Kreuger, [in:] Corpus Iuris Civilis, vol. II, ${ }^{9}$ Berolini 1915 (cetera: CJ).

${ }^{52} \mathrm{CJ}$, IX, 8, 1: Filii vero eius, quibus vitam imperatoria specialiter lenitate concedimus (...) a materna vel avita, omnium etiam proximorum hereditate ac successione habeantur alieni, testamentis extraneorum nihil capiant, sint perpetuo egentes et pauperes, infamia eos paterna semper comitetur, ad nullos unquam honores, nulla
} 
The point that the children should be guaranteed at least a portion of property exempt from garnishment was substantiated by Paulus with the ratio naturalis rule, in that children inherit the property from their father, as well as with the belief that just as nobody should be responsible for the misdeeds of others, so the family of the convict should not suffer poverty due to his misdemeanour:

Cum ratio naturalis quasi lex quaedam tacita liberis parentium hereditatem addiceret, velut ad debitam successionem eos vocando (propter quod et in iure civili suorum heredum nomen eis indictum est ac ne iudicio quidem parentis nisi meritis de causis summoveri ab ea successione possunt): aequissimum existimatum est eo quoque casu, quo propter poenam parentis aufert bona damnatio, rationem haberi liberorum, ne alieno admisso graviorem poenam luerent, quos nulla contingeret culpa, interdum in summam egestatem devoluti..$^{53}$

The above-mentioned argumentation by Paulus corresponds with that used in the rescript issued by the Emperor Hadrian in the largely obscure case against Albinus, a father with a numerous family, whose property was ordered for confiscation:

Sed et divus Hadrianus in hac sententia rescripsit: Favorabilem apud me causam liberorum Albini filiorum numerus facit, cum ampliari imperium hominum adiectione potius quam pecuniarum copia malim: ideoque illis paterna sua concedi volo, quae manifestabunt tot possessores, etiamsi acceperint universa. ${ }^{54}$

The described factual findings indicate that the property must have been rather negligible; therefore, the value of the portion of the inherited property granted to the children would be scarce, essentially leaving the children without means of support. This is why Hadrian decided to exempt the entire property from confiscation, so that the convict's family could claim it, the rationale behind the decision being that he strived to strengthen the authority by winning people's support for the Empire rather than by accumulating funds in the Emperor's treasury. Krzysztof Amielańczyk claims that the Emperor's intention was not only to achieve a cheap propaganda effect - the decision to refrain from confiscating the scant property of the convict would not be detrimental to the State Treasury - since the resolution was compatible with the other socially-benevolent decisions pertaining to fiscal policy ${ }^{55}$.

Another example of a rescript with which Hadrian refrained from property confiscation can be found in a record by Marcian, published in Corpus Juris Civilis, in De bonis eorum qui ante sententiam vel mortem sibi consciverint vel

prorsus, sacramenta perveniant, sint postremo tales, ut his, perpetua egestate sordentibus, sit et mors solatium et vita supplicium. See more: M. DyjaKowsKa, op. cit., p. 71-72.

${ }^{53}$ Dig., XLVIII, 20, 7.

${ }^{54}$ Dig., XLVIII, 20, 7, 3 (Paulus).

55 K. Amielańczyк, Rzymskie prawo karne w reskryptach cesarza Hadriana, Lublin 2006, p. 229. 
accusatorem corruperunt. The rescript was issued with regard to a case where the father charged with murdering his son committed suicide in an act of despair following his son's death. For this case, the Emperor deemed it appropriate to refrain from confiscating the property, as the suicide itself was a sufficient punishment for the defendant:

Videri autem et patrem, qui sibi manus intulisset, quod diceretur filium suum occidisse, magis dolore filii amissi mortem sibi irrogasse et ideo bona eius non esse publicanda divus Hadrianus rescripsit. ${ }^{56}$

The above-mentioned rescript and the cases of suicides committed by the defendants are the subject of considerations on suicide as a method of avoiding penal responsibility, including property confiscation. As a rule, the proceedings were discontinued as the defendant had died: Is, qui in reatu decedit, integri status decedit; extinguitur enim crimen mortalitate $(. . .)^{57}$. By committing suicide, the defendant made it impossible to pass the sentence and, consequently, to confiscate the property, which could be effected only upon the conviction. Therefore, the entire property could be claimed by his heirs, and his will remained valid - as put by Tacitus in Annales, this was supposed to be the reward for being quick to act:

nam promptas eius modi mortes metus carnificis faciebat, et quia damnati publicatis bonis sepultura prohibebantur, eorum qui de se statuebant humabantur corpora, manebant testamenta, pretium festinandi..$^{58}$

The trials described by this author, mentioned earlier, proved that there were exceptions to the crimen extinguitur mortalitate rule. The exception was namely applicable for the crimen maiestatis cases, where, as already explained, the crime was often subject to accusations on the part of political rivals. In his reference to the above rule, Ulpian adds:

(...) nisi forte quis maiestatis reus fuit, nam hoc crimine, nisi a successoribus purgetur, hereditas fisco vindicatur. Plane non quisque legis Iuliae maiestatis reus est, in eadem condicione est, sed qui perduellionis reus est, hostili animo adversus rempublicam vel Principem animatus; ceterum si quis ex alia causa legis Iuliae maiestatis reus sit, morte crimine liberatur. ${ }^{59}$

The exception to the rule is confirmed in a comment by another jurisprudent:

Si propter mortem rei accusator destiterit, non potest hoc senatusconsulto teneri, quia morte rei iudicium solvitur, nisi tale crimen fuit, cuius actio et adversus heredes durat, veluti maiestatis, idem in accusatione repetundarum est, quia haec quoque morte non solvitur. ${ }^{60}$

\footnotetext{
56 Dig., XLVIII, 21, 3, 5.

57 Dig., XLVIII, 4, 1 (Ulpianus).

58 TAcitus, Annales, VI, 28.

59 Dig., XLVIII, 4, 1.

${ }^{60}$ Dig., XLVIII, 16, 15, 3 (Macer).
} 
According to Callistratus' De iure fisci among many causes for commencing a litigation embracing the fiscus one may find the death of a person accused of crimen capitalis and the possibility of continuing (or even launching) a legal proceeding after his death:

Variae causae sunt, ex quibus nuntiatio ad fiscum fieri solet (...) vel eum decessisse, qui in capitali crimine esset: vel etiam post mortem aliquem reum esse $(\ldots)^{61}$.

A perduellio case, understood as a qualified form of crimen maiestatis, i.e. in that the perpetrator deliberately acts to the detriment of the State, continued to be heard even upon his death and, with the deceased defendant being found guilty, property confiscation was adjudged. Even those proceedings that were launched against the perpetrator posthumously could lead to conviction, the words of Modestinus being the confirmation of this:

Ex iudiciorum publicorum admissis non alias transeunt adversus heredes poenae bonorum ademtionis, quam si lis contestata et condemnatio fuerit secuta, excepto repetundarum et maiestatis iudicio, quae etiam mortuis reis, cum quibus nihil actum est, adhuc exerceri placuit, ut bona eorum fisco vindicentur, adeo ut Divus Severus et Antoninus rescripserunt, ex quo quis aliquod ex his causis crimen contraxit, nihil ex bonis suis alienare, aut manumittere eum posse. ex ceteris vero delictis poena incipere $\mathrm{ab}$ herede ita demum potest, si vivo reo accusatio mota est, licet non fuit condemnatio secuta. $^{62}$

Publicatio bonorum was the consequence of a conviction to poena capitalis and not to an additional penalty ${ }^{63}$. Consequently the confiscation was available only if the defendant was found guilty.

However, with the general rule being that the defendant's suicide, preventing the sentence to be passed, deprived the State Treasury of potential profits from property confiscation, the Emperors began to undertake measures to ensure that such a method of avoiding confiscation was impossible to employ. It was not until Hadrian took over the reign that major changes were introduced in that respect, in that the defendants, who in the past, probably as long as until Tiberius came to power, could commit suicide before the sentence had been passed to avoid confiscation by transferring their entire property to their heirs ${ }^{64}$, were no longer to do so. Where there was no conviction in place, a rule applicable in civil proceedings was employed, called confessus pro indicato est, which meant that the suicide committed by a person being aware of committing a crime that was subject to the

${ }^{61}$ Dig., XLIX, 14, 1 pr.

${ }^{62}$ Dig., XLVIII, 2, 20. See more: U. Brasiello, op. cit. p. 124-130; E. Volterra, Processi penali contro $i$ defunti in diritto romano, RIDA 3, 1949, p. 485sqq; C.W. ChILton, The Roman Law of Treason under the early Principate, JRS 45, 1955, p. 72-81.

${ }^{63}$ See more: U. Brasiello, op. cit. p. 130; S. Puliatti, Il $<$ De iure fisci $>$ di Callistrato e il processo fiscale in età severiana, Milano 1992, p. 182.

${ }^{64}$ J. Rominkiewicz, Samobójstwo w prawie rzymskim, AUW.P 288, 2004, p. 64. 
penalty of confiscation was equal to a guilty plea. In order to specify what implications suicide had for the property, it was essential to establish the grounds for such an act, an issue stipulated in the decree issued by Antoninus Pius, appointed by Marcian:

Qui rei postulati vel qui in scelere deprehensi metu criminis imminentis mortem sibi consciverunt, heredem non habent. Papinianus tamen libro sexto decimo digestorum responsorum ita scripsit, ut qui rei criminis non postulati manus sibi intulerint, bona eorum fisco non vindicentur: non enim facti sceleritatem esse obnoxiam, sed conscientiae metum in reo velut confesso teneri placuit. Ergo aut postulati esse debent aut in scelere depehensi, ut, si se interfecerint, bona eorum confiscentur. Ut autem divus Pius rescripsit, ita demum bona eius, qui in reatu mortem sibi conscivit, fisco vindicanda sunt, si eius criminis reus fuit, ut, si damnaretur, morte aut deportatione adficiendus esset. Idem rescripsit eum, qui modici furti reus fuisset, licet vitam suspendio finierit, non videri in eadem causa esse, ut bona heredibus adimenda essent (...). Ergo ita demum dicendum est bona eius, qui manus sibi intulit, fisco vindicari, si eo crimine nexus fuit, ut, si convinceretur, bonis careat. ${ }^{65}$

Hence, in order for the confiscation to be effected, it had to be proved that the suicide was committed to avoid responsibility and penalty for a wrongful act, whereby certain premises had to exist, e.g. a murder charge, which normally resulted in the property being confiscated, the perpetrator being caught in the act or being accused of committing such an act, the awareness of the committed act, as well as the viability of proving the crime. Where it was impossible to prove a different rationale behind the murder, a presumption was made that the defendant took his life out of fear of the looming punishment ${ }^{66}$. Salvatore Puliatti points out that this norm resembles the rule referring to a dowry appointed by the father before he was sentenced. In both cases the fear was taken into consideration on penal sanction. Nonetheless there was an essential procedural difference between them: in the case of suicide a presumption of guilt was made, while as far as the dowry was concerned, it was necessary to prove (nisi probatur) that it had been appointed out of fear of a punishment ${ }^{67}$.

The property was not subject to confiscation where suicide was driven by motives specified in $\$ 4$ and $\$ 5$, quoted above, of the above-mentioned text by Marcian which makes reference to the rescripts issued by Antoninus Caracalla and Hadrian: Si quis autem taedio vitae vel inpatientia doloris alicuius vel alio modo vitam finierit, successorem habere divus Antoninus rescripsit ${ }^{68}$. Thus, for the suicide to be justified, the following grounds had to exist: the incapacity to endure physical pain (impatientia doloris ${ }^{69}$ ), and bereavement following the loss of someone close

\footnotetext{
${ }^{65}$ Dig., XLVIII, 21, 3.

66 Ibidem, p. 65-66.

67 S. Puliatti, op. cit., p. 190.

68 Dig., XLVIII, 21, 4.

69 See also: Dig., XLIX, 16, 6, 7 (Arrius Menander); XXIX, 1, 34 (Papinianus); XLVIII, 19, 38,12 (Paulus); XXI, 1, 43, 4 (Paulus); XXVIII, 3, 6, 7 (Ulpianus); XXIX, 5, 1, 23 (Ulpianus).
} 
(a son, as was the case in the quoted extract XLVIII, 21, 5 - dolor filii amissi). Other separate grounds named by jurists are mental illness $(\text { furor })^{70}$, the feeling of disgrace $(\text { pudor })^{71}$, the longing for fame (iactatio $)^{72}$, and, last but not least, dissatisfaction with life (taedium vitae ${ }^{73}$. The last one is named in the sources of law along the previously mentioned grounds, so it is a separate suicide motive. This would imply that if the suicide was committed due to dissatisfaction with life attributable, e.g., to pain, illness or bereavement, lawyers could qualify such a situation according to the primary ground for committing suicide, that is pain, illness or bereavement, as opposed to dissatisfaction with life as such. Such grounds for committing suicide seem to largely lack clear specification and are hard to define, with legal texts failing to sufficiently clarify the notion of taedium vitae ${ }^{74}$. The grounds for committing suicide found in literary sources include the feeling of being defeated (e.g. a lost battle and the resultant slavery $)^{75}$, political persecution, intimidation (e.g. by the emperors ${ }^{76}$, false accusations, humiliation ${ }^{77}$, a threat to existence and the resultant fear, being in exile without family and support ${ }^{78}$, the will to protect relatives against repressions $\mathrm{s}^{79}$, poverty and the fear of impoverishment, loneliness, disillusionment resulting from the failure to achieve something, as well as motives of a more philosophical and psychological nature, which are most often mentioned by Seneca ${ }^{80}$.

In the case of a suicide committed due to "justified" grounds, the testament of the suicide was due to the statutory heirs, the rule being confirmed by the rescript, mentioned by Ulpian, issued to Pomponius Falco by Emperor Hadrian:

Nam eorum, qui mori magis quam damnaro maluerint ob conscientiam criminis, testamenta irrita constitutiones faciunt, licet in civitate decedant: quod si quis taedio vitae vel valetudinis adversae inpatientia vel iactationis, ut quidam philosophi, in ea causa sunt, ut testamenta eorum valeant. Quam distinctionem in militis quoque testamento Divus Hadrianus dedit Epistola ad Pomponium Falconem, ut, si quidem ob conscientiam delicti militaris mori maluit, irritum sit eius testamentum;

${ }^{70}$ E.g. XLIX, 16, 6, 7 (Arrius Menander).

${ }^{71}$ E.g. l. cit.; XLIX, 14, 45, 2 (Paulus); cf. the rescript issued by Alexander Severus in the year 226, Cd, IX, 50, 2.

72 Dig., XXVIII, 3, 6, 7 (Ulpianus).

73 Dig., XLIX, 16, 6, 7 (Arrius Menander); XXIX, 1, 34 (Papinianus); XLIX, 14, 45, 2 (Paulus); III, 2, 11, 3 (Ulpianus); XXVIII, 3, 6, 7 (Ulpianus); XXIX, 5, 1, 23 (Ulpianus); XLVIII, 21, 3, 4 (Marcianus); XLVIII, 21, 3, 6 (Marcianus).

${ }^{74}$ M. KuryŁowicz, Taedium vitae w rzymskim prawie karnym, [in:] Contra leges et bonos mores. Przestępstwa obyczajowe w starożytnej Grecji i Rzymie, ed. H. KowalsKi, M. KurYŁowicz, Lublin 2005, p. 192-193.

${ }^{75}$ E.g. Plinius, VIII, 186.

76 E.g. Tacitus, Annales, VI, 25; Suetonius, III, 49.

77 Suetonius, IV, 23.

78 Tacitus, Annales, XIV, 59.

${ }^{79}$ L. cit.

80 See more: M. KuryŁowicz, op. cit., p. 196-198. 
quodsi taedio vitae, vel dolore, valere testamentum, aut si intestato decessit, cognatis, aut si non sint, legioni ista sint vindicanda. ${ }^{81}$

In the cited rescript, the validity of the testament of the soldier who took his life was made dependent on whether he committed the act as someone aware of being guilty of a military crime (conscientia delicit militaris), or as a result of being dissatisfied with life or plagued by pain (taedio vitae dolore). A comment made by Papinianus may relate to the same rescript: Eius militis, qui doloris impatientia vel taedio vitae mori maluit, testamentum valere vel intestati bona ab his qui lege vocantur vindicari divus Hadrianus rescripsit ${ }^{82}$.

Where the defendant in a penal case died a natural death, the rule of crimen extinguitur mortalitate was applied, which meant that the proceedings were discontinued without the sentence being passed, with the property being left unconfiscated $^{83}$.

Si qui autem sub incerto causae eventu in vinculis vel sub fideiussoribus decesserint, horum bona non esse confiscanda mandatis cavetur ${ }^{84}$.

Parricidii postulatus si interim decesserit, si quidem sibi mortem conscivit, successorem fiscum habere debebit; si minus, eum quem voluit, si modo testamentum fecit: si intestatus decessit, eos heredes habebit, qui lege vocantur ${ }^{85}$.

When the confiscated property was of considerable value, it was acquired by fiscus through publicatio bonorum; otherwise it was saled to satisfy the creditors:

Si cui aqua et igni interdictum sit, eius nec illud testamentum valet quod ante fecit nec id quod postea fecerit: bona quoque, quae tunc habuit cum damnaretur, publicabuntur aut, si non videantur lucrosa, creditoribus concedentur ${ }^{86}$.

Property confiscation involved the customary practice of depriving the defendant of his personal belongings. Mentioned by Callistratus the rescript issued by the Emperor Hadrian stipulated that such deprivation could take place only with the convict in place, as opposed to when such decision was made with the defendant

${ }^{81}$ Dig., XXVIII, 3, 6, 7. Cf. rescript issued by Alexander Severus in the year 226, CJ, IX, 50, 2: Eorum demum bona fisco vindicantur, qui conscientia delati admissique criminis metuque futurae sententiae manus sibi intulerint. Ea propter fratrem vel patrem tuum si nullo delato crimine, dolore aliquo corporis aut taedio vitae aut furore aut insania aut aliquo casu suspendio vitam finisse constiterit, bona eorum tam ex testamento quam ab intestato ad successores pertinebunt.

${ }^{82}$ Dig., XXIX, 1, 34 pr. Such suicides among soldiers must have been commonplace, since Hadrian addressed this issue in the rescript mentioned by Arrius Menander in Dig., XLIX, 16, 6, 7. See more:

K. Amielańczyk, Roman penal law..., p. 242-243.

83 J. Rominkiewicz, op. cit., p. 69.

${ }^{84}$ Dig., XLVIII, 21, 3, 7 (Marcianus).

${ }^{85}$ Dig., XLVIII, 9, 8 (Ulpianus).

${ }^{86}$ Dig., XXVIII, 1, 8, 1 (Gaius). 
being in jail until the case is closed: Non ut quis in carcerem ductus est, spoliari eum oportet, sed post condemnationem; idque divus Hadrianus rescripsit ${ }^{87}$.

In an another rescript, the same Emperor explained the doubts as to the meaning of the pannicularia notion, which was to be left at the disposal of the convict: this included the clothes that the defendant was wearing at the time of conviction, a small amount of money "for subsistence purposes", as well as low-value jewellery, i.e. worth less than 5 aurea. Valuable items were subject to confiscation; for example the rescript mentions here valuable jewellery or a promissory note for a significant amount of money:

Divus Hadrianus Aquilio Braduae ita rescripsit: Panniculariae causa quemadmodum intellegi debeat, ex ipso nomine apparet; non enim bona damnatorum pannicularia significari quis probe dixerit, nec si zonam circa se habuerit, protinus aliquis sibi vindicare debebit: sed vestem qua is fuerit indutus, aut nummulos in ventralem, quos victus sui causa in promptu habuerit, aut leves anulos, id est quae rem non excedit aureorum quinque. Alioquin si quis damnatus digito habuerit aut sardonychica aut aliam gemmam magni pretii vel si quod chirographum magnae pecuniae in sinu habuerit, nullo iure illud in pannicularia ratione retinebitur. ${ }^{88}$

As may be inferred from the further section of the extract of De officio Proconsulis by Ulpian, from which the reference to the mentioned rescript is taken, the items taken away from the convict were usually transferred to the Emperor's treasury. Ulpian, though, deemed this practice as being "overly zealous", as the imperial legate was obliged to use the items for covering administration costs, e.g. remuneration for the clerks, military equipment or gifts for the deputies, essentially for any purpose that is unrelated to his personal interest ${ }^{89}$.

Hanc rationem non compendio suo debent Praesides vertere, sed nec pati optiones, sive commentarienses ea pecunia abuti, sed debent ad ea servari, quae iure Praesidum solent erogari, ut puta chartiaticum quibusdam officialibus inde subscribere, vel si qui fortiter fecerint milites, inde iis donare, barbaros etiam inde munerari, venientes ad se vel legationis, vel alterius rei causa. Plerumque enim inde corrasas pecunias Praesides ad fiscum transmiserunt; quod perquam nimiae diligentiae est, quum sufficiat, si quis non in usus proprios verterit, sed ad utilitatem officii patiatur deservire. ${ }^{90}$

The above-mentioned extract deals with the important issue of what happened to the property upon its effective confiscation. The records provided by Tacitus indicate that during the early Principate confiscated real properties were

\footnotetext{
${ }^{87}$ Dig., XLVIII, 20, 2.

${ }^{88}$ Dig., XLVIII, 20, 6 (Ulpianus).

${ }^{89}$ See more: K. Amielańczyк, Fiscal Policy..., p. 596. The author admits that it is difficult to specify exactly which emperor was the first to subsidise Provincial authorities with the funds that were officially due to the State Treasury, although such a decision would be consistent with Hadrian's profile, as he was known to be exceptionally active in pursuing his Policy in the Provinces, and very generous in providing financial suport for their development.

90 Dig., XLVIII, 20, 6 (Ulpianus).
} 
so commonly sold that it led to disruptions on the financial market (also caused by attempts at counteracting usury):

Hinc inopia rei nummariae, commoto simul omnium aere alieno, et quia tot damnatis bonisque eorum divenditis signatum argentum fisco vel aerario attinebatur. ad hoc senatus praescripserat, duas quisque faenoris partis in agris per Italiam conlocaret ${ }^{91}$.

The extract deals with what happened to confiscated property which could potentially be acquired by private purchasers through public auction. Fergus Millar's claim that the property adjudged to the treasury was usually kept there, whereas aerarium put such property on sale ${ }^{92}$, is not always supported by the information provided in the sources of law. On the one hand, the Roman Empire retained some parts of the land, at least in Italy, where the Emperors could not get away with accumulating too much goods in private hands. When describing the state administration at the beginning of the reign of Tiberius, Tacitus highlights the fact that only a small portion of the land in Italy (rari per Italiam agri ${ }^{93}$ ) belonged to the Emperor, whereas the statements made by Plinius in which he claimed that Domitian was a monopolist owner of Italian real properties, may be considered an accusation ${ }^{94}$. Over time, the area of the Emperor's estate spread, and they made sure they were the administrators of the other agri publici, although here this process would probably take longer than in the Provinces. On the other hand, though, many sources are a testimony to the fact that fiscus would sell the confiscated properties. For example, in the Digesta, Paulus expressed the opinion, based on the Emperor's decree, that those who purchased land from the treasury without assuming ownership thereof should not be subject to interest since the purchaser had not yet gained benefits from the land ${ }^{95}$. In another extract from Liber singularis ad Orationem divi Severi, the same author discussed the pledge made on property purchased from the treasury ${ }^{96}$. Callistratus, quoted in Dig., XLIX, 14, 3, 5 cited a decree issued by the "divine brothers", i.e. Marcus Aurelius and Lucius Verus, on establishing the price for the sale of property belonging to the treasury: thereunder it was supposed to be calculated based on the actual value of the property, as opposed to the initial purchase price. Ulpian estimated the amount of the eviction for a sold property belonging the treasury at its unitary value ${ }^{97}$. Also, he claimed that where a single item was sold, the right of ownership was due to the purchaser already upon the payment. Pursuant to the rescript issued by Septimius Sever and Antoninus Pius, quoted by Marcian ${ }^{98}$,

\footnotetext{
91 TACitus, Annales, VI, 17.

92 F. Millar, op. cit., p. 37.

93 Tacitus, Annales, IV, 6.

94 Plinius, Panegyricus, 50.

95 Dig., XXII, 1, 16, 1 (Paulus).

96 Dig., XXVII, 9, 2 (Paulus).

97 Dig., XLIX, 14, 5, pr.-1.

${ }^{8}$ Dig., XLIX, 12, 22, pr.
} 
the Emperor's proxy (procurator Caesaris) was obliged to hold back the sale of the individual items of the lese-majesty convict's property upon the convict's death, with the proceedings being further carried out with the heir; according to the jurist, the sales of an item with the trial in progress should basically not take place. There was no doubt that the primary goal of the sales was to gain cash, while sometimes it was pursued on other economic grounds, such as the unprofitability of maintaining low-acreage land separated from larger compounds of the Emperor's estates ${ }^{99}$.

Although not a crucial source of revenue, items and estates gained through the confiscation of property accounted for a major fund supply for the State Treasury (aerarium). Despite the financial penalties having other functions as well such as to compensate for a misdeed or to deter - the only explanation that springs to mind as to why it was so commonly employed during the Roman Empire is that the emperors were striving to accumulate State-owned and, over time, to a consistently larger extent, their own funds. The convict's fate, his detriment and the impoverishment of him and his family were taken into consideration on an exceptional basis.

\begin{abstract}
The paper discusses the confiscation of property (publicatio bonorum) as a source of revenue for the fiscus in ancient Rome. The term fiscus means, among other things, the public property, State funds, but also the private property of emperors. The confiscated property could be adjudged not only to aerarium - the State Treasury (publicare), but also to the personal treasury of emperors, and trials seem to have been inspired to supply it. The most „successful” accusation was connected with the crime of lese-majesty: the scope of this crime was especially wide and it was easy to convict the defendant. The Senate often voted for adjudgement of the confiscated property in respect of the Emperor, especially if the convict had received some benefits from him. This practice turned into a rule and the Emperor's treasury became the sole beneficiary of publicatio bonorum. Some emperors are especially known as rulers accumulating their private property on confiscated goods (Caligula, Septimius Severus, Domitian). A portion of those goods was due to the children of the defendant; some rescripts issued by the emperors even ordered to transfer his whole property in the first place to his descendants. In spite of the rule that it was necessary to find the defendant guilty to confiscate his property, the publicatio bonorum was not available; when he committed suicide before the sentence, a presumption was made that this act was equal to a guilty plea. According to another rule - confessus pro indicato est - the defendant was convicted unless his suicide was justified. The personal belongings (pannicularia) were to be confiscated, too, but only after the conviction.
\end{abstract}

Marzena Dyjakowska

Katedra Historii Państwa i Prawa

Wydział Prawa, Prawa Kanonicznego i Administracji Katolicki Uniwersytet Lubelski Jana Pawła II

Al. Racławickie 14

20-950 Lublin, Polska marzena.dyjakowska@kul.lublin.pl

99 P.A. BRUnT, op. cit., p. 88. 